\title{
METHODICAL APPROACHES TO ANALYSIS OF THE SPECIFIC REGIONAL NATURAL USAGE IN GEO-PLANNING ANALYSIS OF TERRITORY
}

\author{
Daria MALCHYKOVA
}

\author{
Kherson State university, Ukraine \\ darina13@i.ua
}

\begin{abstract}
The article deals with methodical approaches to the analysis of the specific features of regional nature management in the formation of geo-planning structure in rural areas. It shows the possibility to apply factor analysis for the study of regional nature usage. The taxonomy of regional levels and forms of geo-planning organization of rural areas is presented at the base, integrated and network levels. The model testing of the techniques, allowing picking out geo-planning microregions, was conducted on the example of Kherson region.
\end{abstract}

Key words: territorial planning of region, rural areas, natural usage, geo-planning analysis, planning management.

UDC: 911.3:711.1.25

\section{МЕТОДИЧНІ ПІДХОДИ ДО АНАЛІЗУ СПЕЦИФІКИ РЕГІОНАЛЬНОГО ПРИРОДОКОРИСТУВАННЯ У ГЕОПЛАНУВАЛЬНОМУ АНАЛІЗІ ТЕРИТОРІЇ}

\author{
Дар'я МАЛьЧИКОВА \\ Херсонський державний університет, Україна \\ darina13@i.ua
}

\begin{abstract}
Анотація: У статті розглянуто методичні особливості аналізу специфіки регіонального природокористування в процесі формування геопланувальної структури сільської місцевості; показано можливості застосування факторного аналізу у регіональному аналізі природокористування. Представлено таксономію регіональних рівнів і форм геопланувальної організації сільської місцевості на базовому, комплексному і мережевому рівні. Здійснено модельне апробування методики виділення геопланувальних мікрорегіонів на прикладі Херсонського регіону.

Ключові слова: планування територій регіонів, сільська місцевість, природокористування, геопланувальний аналіз,
\end{abstract} планувальна організація.

удк: $911.3: 711.1 .25$

Постановка проблеми. Сьогодні в Україні маємо розвинену методологію i методику планування територій на загальнодержавному рівні, яка знайшла своє відображення (і законодавче оформлення) в унікальній для країни Генеральній схемі планування території України. Давню історію i розвинуту практику має розробка документації 3 планування міст і промислових районів, на сьогодні наявна i уніфікована методика формування схем планування територій обласних регіонів. Разом 3 тим, до цього часу не дістали відповідного наукового обгрунтування методологічні і методичні підходи планування територій сільської місцевості на регіональному рівні, є нечисленними дослідження відмінностей геопросторової організації і умов розвитку сільської місцевості (CM), які формують належне підгрунтя для планувальної діяльності в межах сільських територій різних масштабів і типів.

3 огляду на наявні проблеми управління регіональним розвитком i особливості функціонування сільської місцевості на регіональному рівні, зважаючи на недоліки сучасної планувальної організації сільських територій, вважаємо, що удосконалення підходів геопланувального аналізу сільської місцевості для потреб планування на

(с) Д. Мальчикова регіональному рівні є одним 3 актуальних напрямів дослідження фахівців із суспільної географії.

Аналіз останніх публікацій та досліджень. На сьогоднішній день існує чітка ієрархізована система інтегральних форм територіальної організації суспільства $[5 ; 7 ; 13 ; 14 ; 16 ; 18]$, яка адекватно відображає об'єктивну територіальну структуризацію суспільства і слугує базисом для розробки прогнозних моделей розвитку регіонів, заходів регіональної політики держави і планування територій, є засобом підтримки управлінських рішень [12; 15]. Розроблені також численні методи і підходи географічного [3; 4; $10 ; 17]$, містобудівного [1; 11], управлінського аналізу території [2; 9], оцінки територіальних ресурсів [19] тощо. Маємо також розроблену методологічну i методичну схему формування геопланувальної структури сільської місцевості в контексті визначених в специфічних рис іiі функціонування [8]. Саме ці праці стали підгрунтям удосконалення підходів геопланувального аналізу сільської місцевості для потреб планування на регіональному рівні.

Метою роботи стало розглянути методичні особливості аналізу специфіки регіонального природокористування в процесі формування геопланувальної структури сільської місцевості; здійснити модельне апробування застосування факторного аналізу у регіональному аналізі 
природокористування в процесі формування геопланувальної структури сільської місцевості.

Виклад основного матеріалу дослідження. Оцінка території з погляду цілей розвитку суспільства, забезпечення збалансованого регіонального розвитку i формування повноцінного життєвого середовища дозволяє визначити закономірності просторової взаємодії різних сфер життєдіяльності суспільства і здійснити в процесі планування територій моделювання іiі планувальної організації. В контексті геопланування сільської місцевості на регіональному рівні таке моделювання дозволяє:

- розкрити передумови і обмеження розвитку в часі і просторі різних видів природокористування i показати можливості їх комбінації;

- встановити просторові відмінності цих умов;

- встановити оптимальний режим розвитку окремих територій;

- обгрунтувати шляхи найбільш ефективного використання природних i економічних ресурсів, охорони і збагачення природного середовища.

В результаті моделювання геопланувальної організації території з'являється можливість здійснювати не тільки просторову організацію, але i передбачити профіль i масштаби розвитку господарського комплексу регіональної територіальної системи. Це моделювання забезпечує збалансований регіональний розвиток, заснований на ідеях еколого-соціально-економічної рівноваги. Отже процес геопланувальної організації території за своєю сутністю - це їі моделювання.

Загальновизнано, що об’єктами планувальної організації $\epsilon$ просторові соціально-економічні системи різних ієрархічних рівнів. У контексті вирішення завдань геопланування СМ представляє поліструктурне, системне, багатофункціональне утворення - суспільно-просторові комплекси, утворені на основі взаємодії природної, соціальної та економічної складових, що характеризуються розташуванням за межами урбанізованих територій i наявністю специфічних ознак (чисельність, густота населення, види природокористування). Суспільно-географічний аналіз функцій СМ показав їх різноплановість та взаємозумовленість, високу залежність від геопросторової неоднорідності CM, що пояснює регіональні відмінності у природокористуванні i формує основу геопланувальної організації СМ на регіональному рівні. Специфіка геопланування СМ зумовлена тим, що 3 одного боку СМ є антиподом урбанізованої та індустріалізованої території, а 3 іншого - $€$ обов'язковою складовою і умовою збалансованого еколого-економічного розвитку країн та регіонів. На відміну від наявних у ГСП підходів виділення функціональних типів сільськогосподарського використання території за зональноспеціалізованими виробництвами агропромислового комплексу, запропонований підхід акцентує комплексне врахування можливих варіацій поєднання рурального природокористування 3 іншими видами використання територій, поліфункціональність $\mathrm{CM}$, визначну роль ландшафтної структури території та можливостей виконання територіями СМ природоохоронних та екомережевих функцій. Разом 3 тим, зважаючи на специфічні риси сільської місцевості, перш за все різке переважання руральних видів природокористування і фактично континуальний характер, геопланувальна організація сільської місцевості на регіональному рівні може здійснюватись лише через аналіз видів природокористування і їх поєднань.

Відповідно до змісту поняття геопланування, представленому в наших роботах [8], планувальна організація суспільно-просторових комплексів сільської місцевості може бути визначена як раціональне просторове поєднання функціонально-територіальних елементів - видів природокористування та їх комбінацій, об'єднаних структурами управління 3 метою створення та підтримання повноцінного життєвого середовища, забезпечення збалансованого регіонального розвитку і підвищення якості життя населення. При цьому, звичайно, обов'язковим буде співвідношення складових елементів i форм геопланувальної організації з концептуальними положеннями теорії раціональної територіальної організації суспільства.

Відповідно до розроблених методологічних настанов i методичних підходів [8], можна представити таксономію регіональних рівнів і форм геопланувальної організації сільської місцевості (табл. 1).

Запропонована таксономія регіональних рівнів i форм геопланувальної організації сільської місцевості представлена на базовому рівні геопланувальними ареалами (виділяються за видами земельних угідь, які формують відповідний тип землекористування), на комплексному рівні геопланувальними мікрорегіонами - функціональними зонами (виділяються запоширення однорідних ландшафтних місцевостей i відповідних сільськогосподарських типів земель) або планувальними ділянками (за специфікою розселенської структури і комбінацією видів природокористування). За наявністю мереживних форм природокористування в якості особливих складових геопланувальної організації СМ виділено геопланувальні мережі - спеціалізовані монофункціональні, або 3 певним рівнем інтеграції мережевих елементів, наприклад, транспортнокомунікаційні мережі.

На відміну від виділення функціональних типів сільськогосподарського використання території у Генеральній схемі планування території України [6] (виділення зональноспеціалізованих виробництв агропромислового комплексу відповідно до агрокліматичних умов), запропонований підхід акцентує:

- комплексне врахування всіх складових розвитку сільських територій, īi поліфункціональності;

- визначну роль ландшафтної структури території як основи формування сільськогосподарських типів земель i формування особливостей їх використання;

- врахування варіацій поєднання рурального природокористування 3 іншими видами 
природокористування;

- врахування поширення урбанізаційних ознак природокористування як невідємної риси розвитку СМ в сучасних умовах

- аналіз можливостей виконання територіями СМ природоохоронних функції та територіальних ресурсів розбудови регіональної екомережі (оскільки саме СМ зосереджує середовищестабілізуючі та екомережеві елементи, що забезпечують збалансований розвиток всього суспільства).

Прикладом модельного апробування застосування факторного аналізу у регіональному аналізі природокористування в процесі формування геопланувальної структури сільської місцевості можна вважати наші розробки, виконані на прикладі території Херсонської області. Згідно методичної схеми геопланування було проведено аналіз специфіки природокористування та опрацьовані статистичні дані, що характеризують природокористування регіону (табл. 2).

Для групування чинників формування відмін у природокористуванні, редукції великої кількості статистичних показників, було використано факторний аналіз, який дозволив виділити за групуванням ознак природокористування 11 факторів, з яких ми обрали 7 провідних факторів, спираючись на аналіз графіку дисперсій факторних навантажень показників природокористування сільських районів Херсонської області (рис. 1):
А) специфіки сільськогосподарського використання (посівних площ);

Б) ерозійної небезпеки;

В) дефляційної небезпеки;

Г) поширення середовищестабілізуючих елементів землекористування;

Д) поширення руральних ознак СМ;

Е) поширення урбаністичних ознак CM;

Ж) солонцюватості грунтів.

Ці 7 факторів в цілому накопичують 72,3\% відсотків частки загальної дисперсії, що дозволяе говорити про їх значущість. Для аналізу найбільш вагомих чинників формування специфіки природокористування та просторових особливостей їх впливу були визначені значення (ваги) факторів природокористування сільських районів Херсонської області (табл. 3).

Також були побудовані статистичні поверхні розподілу значення факторів природокористування в межах Херсонської області (рис. 2) та побудовані дендрограми типізації сільських районів Херсонської області за значенням факторів природокористування (рис. 3).

Регіональний аналіз специфіки природокористування, проведений за запропонованими методами і підходами дає змогу виділити декілька типів суспільно-просторових комплексів сільських районів, подібних за поширенням поєднань певних типів природокористування:

Таблиияя 1

Таксономія регіональних рівнів і форм геопланувальної організації сільської місцевості

\begin{tabular}{|c|c|c|c|c|c|}
\hline 焉 & 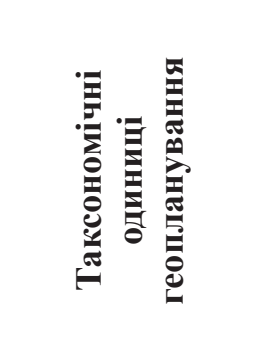 & 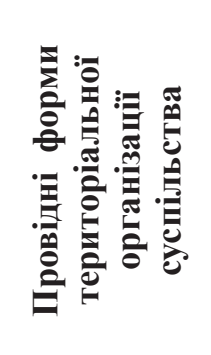 & 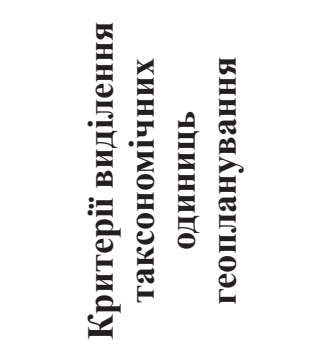 & 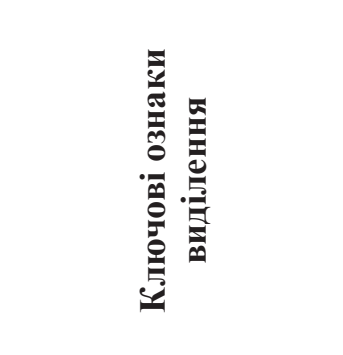 & 0 \\
\hline Базовий & $\begin{array}{c}\text { Геопланувальні } \\
\text { ареали }\end{array}$ & $\begin{array}{l}\text { Агломера- } \\
\text { тивні, } \\
\text { локальні } \\
\end{array}$ & $\begin{array}{c}\text { Тип землекористу- } \\
\text { вання }\end{array}$ & $\begin{array}{c}\text { Види земельних } \\
\text { угідь }\end{array}$ & $\begin{array}{l}\text { Первинні } \\
\text { ареальні }\end{array}$ \\
\hline \multirow[b]{2}{*}{ Комплексний } & $\begin{array}{c}\text { Геопланува- } \\
\text { льні ділянки } \\
\text { (функціональні } \\
\text { зони) }\end{array}$ & $\begin{array}{l}\text { Ареальні, } \\
\text { агломера- } \\
\text { тивні }\end{array}$ & $\begin{array}{c}\text { Тип природокори- } \\
\text { стування }\end{array}$ & $\begin{array}{c}\text { Ландшафтні } \\
\text { місцевості і } \\
\text { сільськогосподарські } \\
\text { типи земель }\end{array}$ & \multirow{2}{*}{$\begin{array}{c}\text { Комплексні } \\
\text { (інтегральні) } \\
\text { ареальні }\end{array}$} \\
\hline & $\begin{array}{c}\text { Геопланувальні } \\
\text { мікрорегіони }\end{array}$ & $\begin{array}{l}\text { Регіональні, } \\
\text { ареальні }\end{array}$ & $\begin{array}{c}\text { Тип суспільно- } \\
\text { територіальних } \\
\text { комплексів }\end{array}$ & $\begin{array}{c}\text { Розселенська } \\
\text { структура і } \\
\text { комбінація видів } \\
\text { природокорис- } \\
\text { тування }\end{array}$ & \\
\hline Мереживний & $\begin{array}{c}\text { Геопланувальні } \\
\text { мережі }\end{array}$ & Лінійні & $\begin{array}{c}\text { Тип природних } \\
\text { та соціально- } \\
\text { економічних мереж }\end{array}$ & $\begin{array}{c}\text { Мереживні форми } \\
\text { природокорис- } \\
\text { тування }\end{array}$ & $\begin{array}{c}\text { Спеціалізовані } \\
\text { та інтегральні } \\
\text { лінійно- } \\
\text { мереживні }\end{array}$ \\
\hline
\end{tabular}


Таблиияя 2

Статистичні показники, що характеризують природокористування в межах сільських районів Херсонської області

\begin{tabular}{|c|c|}
\hline Ознака & \\
\hline $\mathrm{X} 1$ & Середній розмір землекористування, га \\
\hline $\mathrm{X} 2$ & Частка сільськогосподарських угідь, \% \\
\hline $\mathrm{X} 3$ & Частка ріллі, \% \\
\hline $\mathrm{X} 4$ & Частка багаторічних насаджень, \% \\
\hline $\mathrm{X} 5$ & Частка сіножатей, \% \\
\hline $\mathrm{X} 6$ & Частка пасовищ, \% \\
\hline $\mathrm{X} 7$ & Частка земель під сільською забудовою, \% \\
\hline $\mathrm{X} 8$ & Частка земель під міською забудовою, \% \\
\hline $\mathrm{X} 9$ & Частка земель під промисловою забудовою, \% \\
\hline $\mathrm{X} 10$ & Частка лісів і лісовкритих площ, \% \\
\hline $\mathrm{X} 11$ & Частка заболочених земель, \% \\
\hline $\mathrm{X} 12$ & Частка відкритих земель з особливим рослинним покривом або без нього, \% \\
\hline $\mathrm{X} 13$ & Частка земель під природними водоймами, \% \\
\hline $\mathrm{X} 14$ & Частка земель під штучними водоймами, \% \\
\hline $\mathrm{X} 15$ & Частка зрошуваних земель, \% \\
\hline $\mathrm{X} 16$ & Середній вміст в грунті гумусу, \% \\
\hline $\mathrm{X} 17$ & Середній вміст в грунті рухомого фосфору, (мг/кг) $\mathrm{P}_{2} \mathrm{O}_{5}$ \\
\hline $\mathrm{X} 18$ & Середній вміст в грунті обмінного калію, (мг/кг) \\
\hline $\mathrm{X} 19$ & Характеристика сільськогосподарських земель за якісним станом грунтів: частка засолених земель, \% \\
\hline $\mathrm{X} 20$ & Характеристика сільськогосподарських земель за якісним станом грунтів: частка солонцюватих земель, \% \\
\hline $\mathrm{X} 21$ & Характеристика сільськогосподарських земель за якісним станом грунтів: частка земель з солонцевими комплексами, \% \\
\hline $\mathrm{X} 22$ & Характеристика сільськогосподарських земель за якісним станом грунтів: частка перезволожених земель, \% \\
\hline $\mathrm{X} 23$ & Частка природних територій в агроландшафтах, \% \\
\hline $\mathrm{X} 24$ & Територіальна продуктивність земельного потенціалу (бал) \\
\hline $\mathrm{X} 25$ & Середній бал бонітету по району ріллі \\
\hline $\mathrm{X} 26$ & Середній бал бонітету по району пасовищ \\
\hline $\mathrm{X} 27$ & Зазнають дії водної ерозії (слабозмиті), \% від загальної площі \\
\hline $\mathrm{X} 28$ & Зазнають дії водної ерозії (середньозмиті), \% від загальної площі \\
\hline $\mathrm{X} 29$ & Зазнають дії водної ерозії (сильнозмиті), \% від загальної площі \\
\hline $\mathrm{X} 30$ & Розмиті грунти та виходи порід, \% від загальної площі \\
\hline $\mathrm{X} 31$ & Зазнають дії вітрової ерозії (слабодефльовані), \% від загальної площі \\
\hline $\mathrm{X} 32$ & Зазнають дії вітрової ерозії (середньодефльовані), \% від загальної площі \\
\hline $\mathrm{X} 33$ & Зазнають дії вітрової ерозії (сильнодефльовані), \% від загальної площі \\
\hline $\mathrm{X} 34$ & Слабодефляційно-небезпечні сільськогосподарські угіддя, частка у \% \\
\hline $\mathrm{X} 35$ & Середньодефляційно-небезпечні сільськогосподарські угіддя, частка у \% \\
\hline $\mathrm{X} 36$ & Сильнодефляційно-небезпечні сільськогосподарські угіддя, частка у \% \\
\hline $\mathrm{X} 37$ & Охоплено сумісно водною і вітровою ерозією \\
\hline $\mathrm{X} 38$ & Відношення ріллі до середовищестабілізуючих угідь, \% \\
\hline $\mathrm{X} 39$ & Всього зернові, частка посівів у \% від загальної площі ріллі \\
\hline $\mathrm{X} 40$ & Озимі, частка посівів у \% від загальної площі ріллі \\
\hline $\mathrm{X} 41$ & Ярі зернові, круп'яні, частка посівів у \% від загальної площі ріллі \\
\hline $\mathrm{X} 42$ & Кукурудза, частка посівів у \% від загальної площі ріллі \\
\hline $\mathrm{X} 43$ & Зерно-бобові, частка посівів у \% від загальної площі ріллі \\
\hline $\mathrm{X} 44$ & Всього технічні, частка посівів у \% від загальної площі ріллі \\
\hline $\mathrm{X} 45$ & Цукрові буряки, частка посівів у \% від загальної площі ріллі \\
\hline $\mathrm{X} 46$ & Соняшник, частка посівів у \% від загальної площі ріллі \\
\hline $\mathrm{X} 47$ & Картопля, овочі, баштанні, частка посівів у \% від загальної площі ріллі \\
\hline $\mathrm{X} 48$ & Всього кормові, частка посівів у \% від загальної площі ріллі \\
\hline $\mathrm{X} 49$ & Корнеплоди та баштані, частка посівів у \% від загальної площі ріллі \\
\hline $\mathrm{X} 50$ & Кукурудза на силос і зелений корм, частка посівів у \% від загальної площі ріллі \\
\hline $\mathrm{X} 51$ & Однорічні, частка посівів у \% від загальної площі ріллі \\
\hline $\mathrm{X} 52$ & Багаторічні, частка посівів у \% від загальної площі ріллі \\
\hline $\mathrm{X} 53$ & Чисті пари, \% \\
\hline $\mathrm{X} 54$ & Загальна посівна площа ерозійно-небезпечних культур та пар, \% до площі ріллі \\
\hline
\end{tabular}




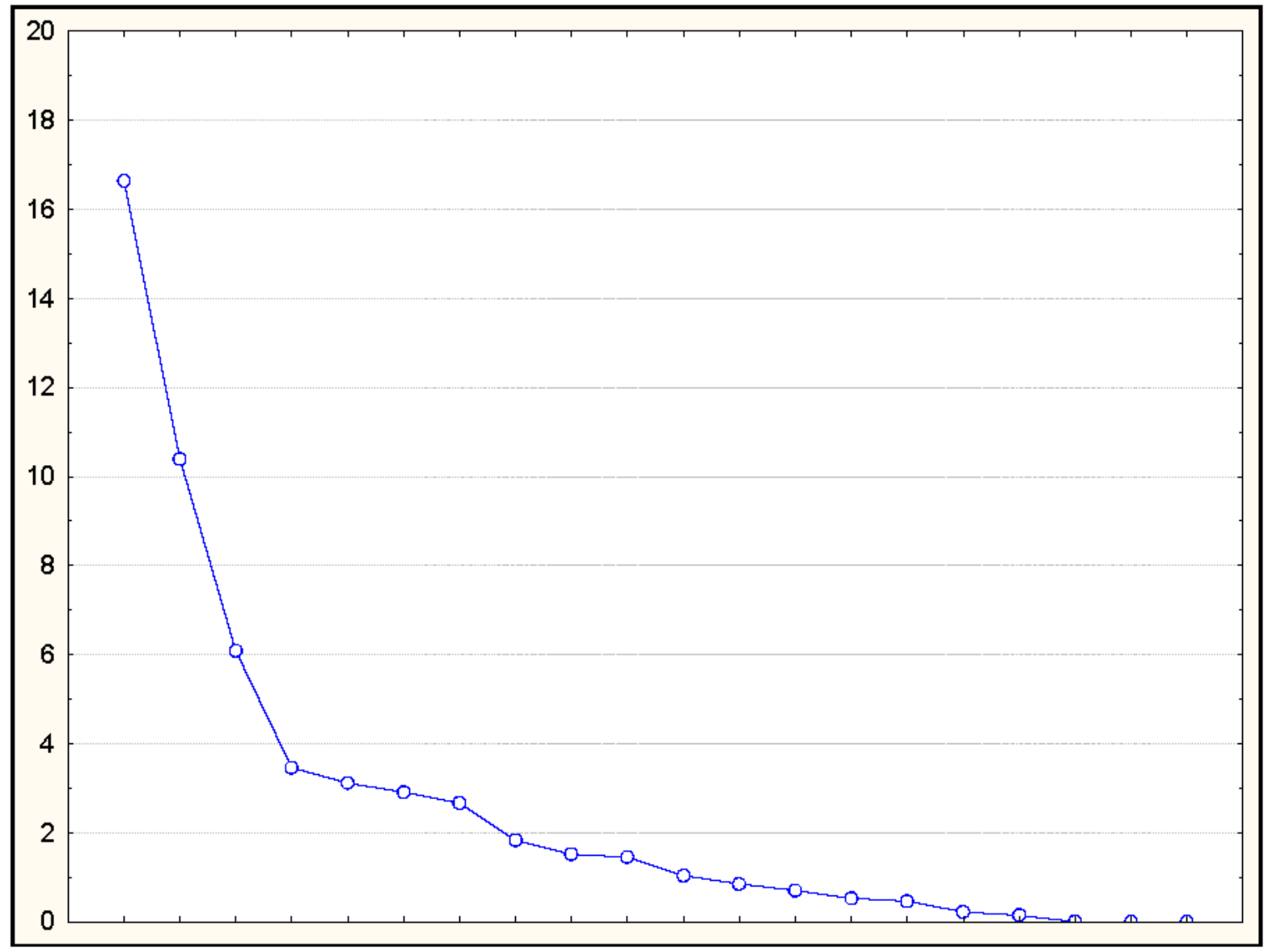

Рис. 1. Графік дисперсій факторних навантажень показників природокористування сільських районів Херсонської області

Таблиия 3

Значення (ваги) факторів природокористування сільських районів (СР) Херсонської області*

\begin{tabular}{|c|c|c|c|c|c|c|c|c|c|c|c|}
\hline CP & $\begin{array}{c}\text { Фактор } \\
1\end{array}$ & $\begin{array}{c}\text { Фактор } \\
2\end{array}$ & $\begin{array}{c}\text { Фактор } \\
3\end{array}$ & $\begin{array}{c}\text { Фактор } \\
4\end{array}$ & $\begin{array}{c}\text { Фактор } \\
7\end{array}$ & $\begin{array}{c}\text { Фактор } \\
6\end{array}$ & $\begin{array}{c}\text { Фактор } \\
7\end{array}$ & $\begin{array}{c}\text { Фактор } \\
8\end{array}$ & $\begin{array}{c}\text { Фактор } \\
9\end{array}$ & $\begin{array}{c}\text { Фактор } \\
10\end{array}$ & $\begin{array}{c}\text { Фактор } \\
11\end{array}$ \\
\hline 1 & $-0,35451$ & $-1,43481$ & 0,48802 & $-1,66056$ & 2,11757 & $-0,22737$ & 1,51459 & 0,09234 & 0,17038 & $-0,31944$ & $-0,68516$ \\
\hline 2 & 0,61669 & $-1,65594$ & 1,42099 & 1,16062 & $-0,43359$ & $-0,32687$ & 1,25326 & 0,45176 & 1,82100 & $-0,52178$ & 0,07374 \\
\hline 3 & $-1,07146$ & 0,29242 & $-0,20898$ & 0,01723 & $-0,93577$ & 0,77327 & $-0,90371$ & $-0,70225$ & 1,12905 & $-0,24851$ & $-1,86320$ \\
\hline 4 & $-1,01766$ & $-0,22599$ & $-0,32985$ & $-0,10245$ & $-0,23567$ & $-1,56222$ & $-0,58732$ & 1,07088 & $-0,44366$ & $-0,33327$ & $-0,25534$ \\
\hline 5 & $-1,14256$ & $-0,49490$ & $-0,36293$ & $-1,46637$ & $-0,24782$ & 1,34836 & 0,18363 & $-0,78441$ & $-1,22522$ & $-0,62174$ & 1,12081 \\
\hline 6 & $-0,97893$ & $-0,71474$ & 0,72616 & 0,01975 & $-1,95354$ & $-1,62765$ & $-0,66090$ & 0,64501 & $-0,51204$ & $-0,18919$ & 1,08931 \\
\hline 7 & 0,28316 & 1,11214 & $-1,13526$ & 0,37022 & $-0,52160$ & 0,19403 & 1,66890 & $-0,64701$ & 1,14189 & $-0,55790$ & 1,94763 \\
\hline 8 & 1,65144 & $-0,47817$ & $-1,76195$ & $-0,63295$ & $-0,92049$ & 1,01055 & 0,32748 & 2,10762 & $-0,89045$ & $-0,40033$ & $-0,35260$ \\
\hline 9 & $-1,01754$ & 0,11260 & $-0,39895$ & 0,79114 & 0,59329 & 1,20596 & $-0,28655$ & 1,11717 & 0,62029 & 0,67108 & 0,00573 \\
\hline 10 & $-0,31698$ & 1,06498 & $-0,23437$ & 0,44944 & 0,41485 & $-1,60324$ & 1,53827 & $-0,29919$ & $-1,68431$ & 0,85819 & $-1,09637$ \\
\hline 11 & 1,02460 & 1,11181 & 0,56267 & $-1,78105$ & 1,17488 & $-0,82783$ & $-1,85366$ & 0,67519 & 1,14988 & $-0,02276$ & 0,78341 \\
\hline 12 & $-0,08618$ & $-0,13106$ & 0,78426 & 1,94406 & 1,62904 & 0,71943 & $-0,97508$ & $-0,18723$ & $-1,45712$ & $-0,91513$ & 1,30231 \\
\hline 13 & $-1,12158$ & 0,81458 & $-1,47496$ & 0,42960 & 0,71797 & $-0,45997$ & 0,01543 & $-0,13840$ & 1,15652 & 1,09441 & 0,30355 \\
\hline 14 & $-0,70093$ & $-0,67242$ & 0,74131 & $-0,54543$ & $-0,66331$ & 1,19247 & $-0,37392$ & $-0,91171$ & $-0,05483$ & 1,01725 & $-0,42322$ \\
\hline 15 & 0,75974 & 1,70815 & 1,16253 & $-0,64381$ & $-0,75514$ & $-0,00325$ & 0,40881 & $-1,19881$ & $-0,22726$ & $-1,50975$ & $-0,50154$ \\
\hline 16 & 1,40146 & 0,19267 & 1,16126 & $-0,01772$ & $-0,45171$ & 0,47229 & 0,13564 & $-0,10717$ & $-0,48539$ & 2,89465 & 0,48233 \\
\hline 17 & 1,58813 & $-1,56354$ & $-1,64639$ & 0,58058 & 0,21650 & $-0,89857$ & $-1,18364$ & $-2,07972$ & $-0,04733$ & $-0,10000$ & $-0,46788$ \\
\hline 18 & 0,48311 & 0,96222 & 0,50643 & 1,08769 & 0,25454 & 0,62060 & $-0,22125$ & 0,89593 & $-0,16140$ & $-0,79580$ & $-1,46350$ \\
\hline
\end{tabular}

*Оцінку факторів було проведено з використанням програмного забезпечення Surfer (метод Кригінга) 


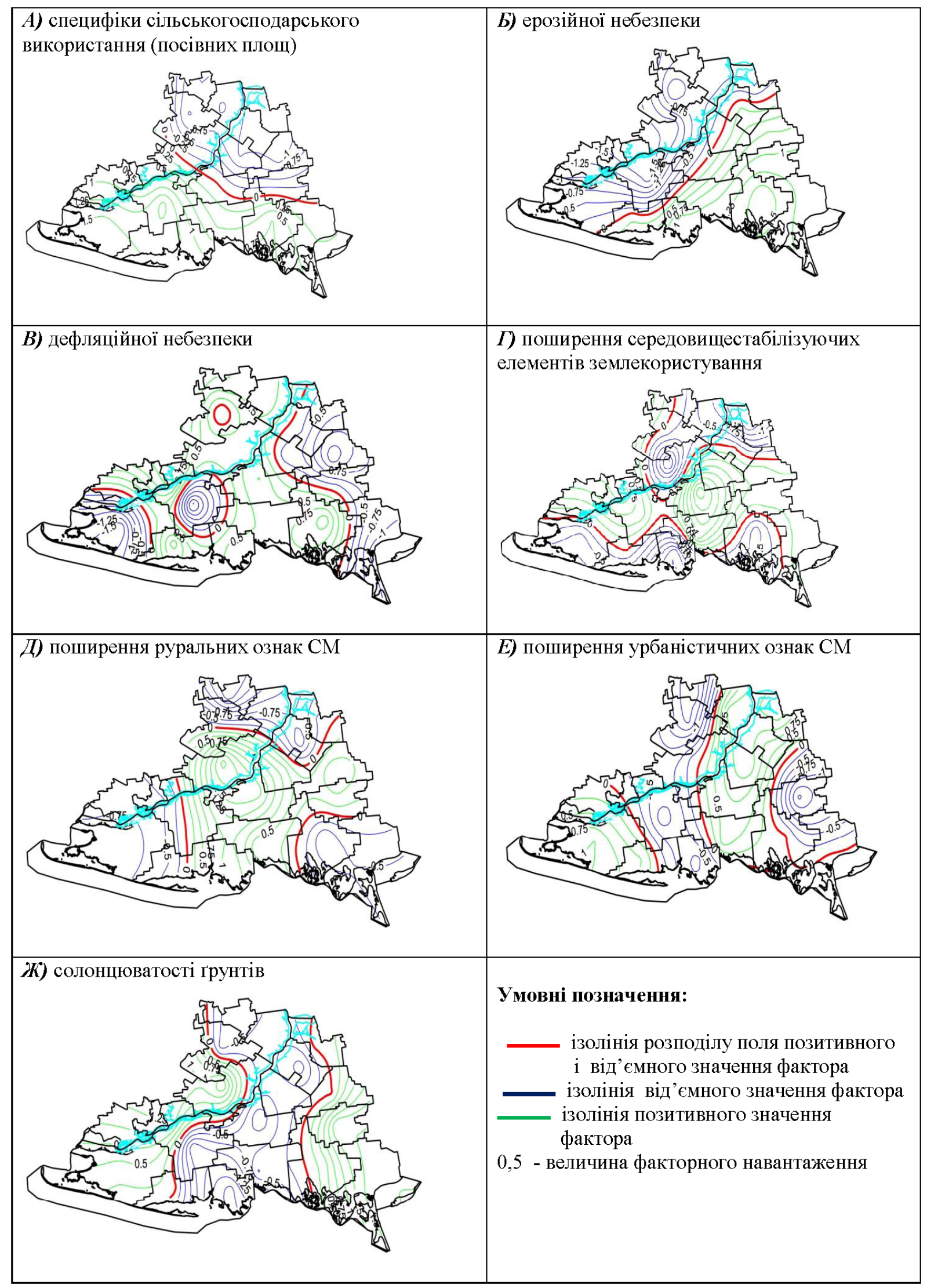

Рис. 2. Статистичні поверхні розподілу значення факторів природокористування в межах Херсонської області 


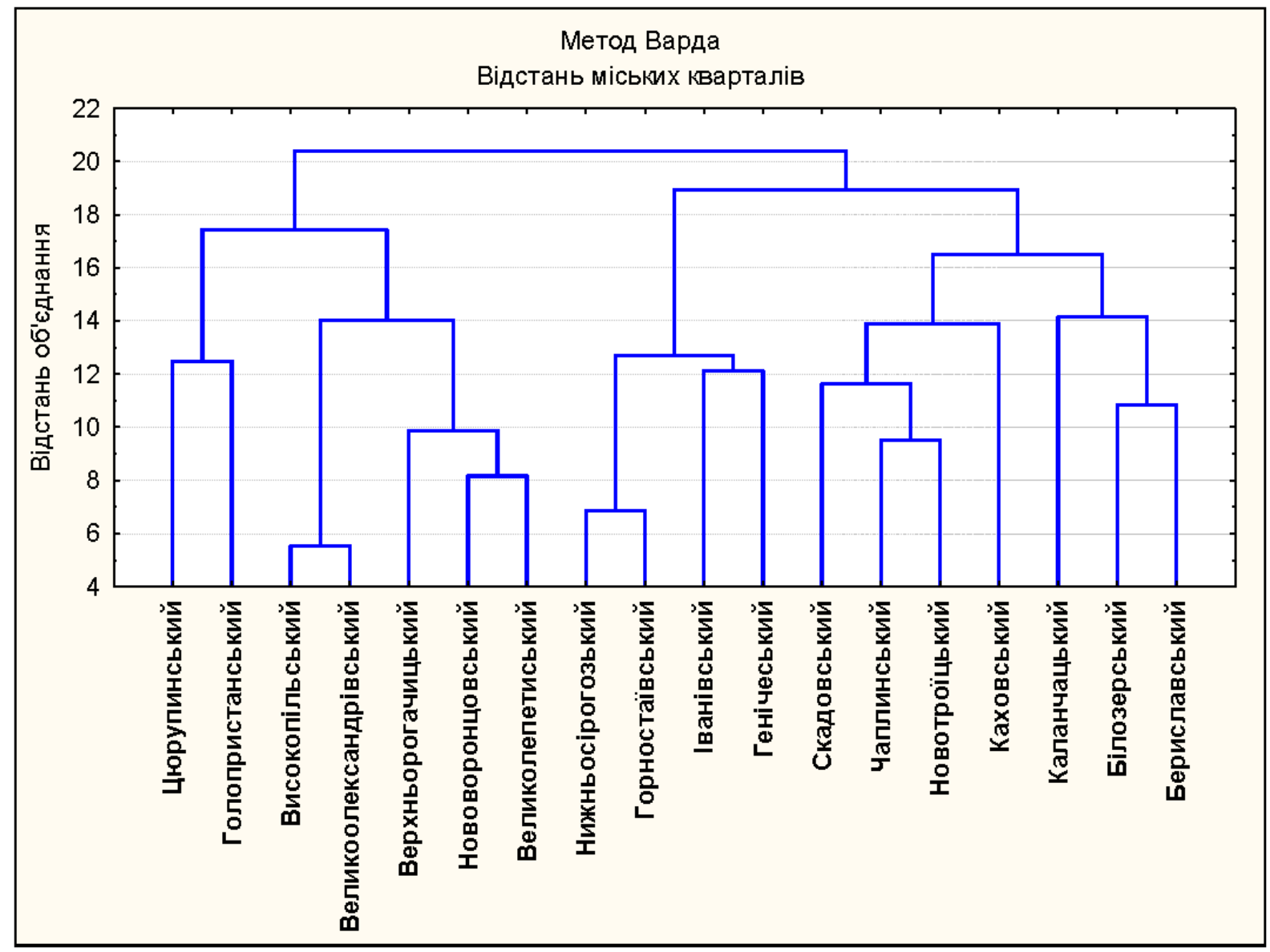

Рис. 3. Дендрограма типізації сільських районів Херсонської області за значеннями факторів природокористування

1) суспільно-просторові комплекси 3 розвитком руральних видів природокористування та перспективним розвитком урбанізаційного природокористування, з високим ризиком ерозійної небезпеки, відносно безпечним дефляційним режимом, без впливу фактору солонцюватості грунтів. (території Бериславського, Білозерського адміністративних районів);

2) суспільно-просторові комплекси з розвитком руральних видів природокористування (3 максимальними показниками сільськогосподарського освоєння) та поширенням урбанізаційного природокористування, 3 високим ризиком ерозійної небезпеки, ризиками осолонцювання грунтів, низьким потенціалом розвитку інших видів природокористування (Великоолександрівський, Високопільський райони);

3) суспільно-просторові комплекси з розвитком руральних видів природокористування (3 максимальними показниками сільськогосподарського освоєння та руралізаціі) та відносно сильними для периферійних районів субурбанізаційним ознаками, ерозійно-небезпечні, 3 низькою часткою середовищестабілізуючих угідь (Великолепетиський, Верхньорогачицький, Нововоронцовський райони);

4) суспільно-просторові комплекси 3 поширенням рурального природокористування, високою дефляційною небезпекою, ризиками солонцюватості грунтів, необхідністю формування i розвитку елементів екомережі; характерний максимальний прояв руральних ознак, найвищі показники сільськогосподарського освоєння і розораності території (у складі Горностаївського та Нижньосірогозького районів), на окремих ділянках специфічне поєднання гідромеліоративноземлеробського, природоохоронного і приморськорекреаційного природокористування (в межах Генічеського та Іванівського районів).

5) суспільно-просторові комплекси 3 поширенням гідромеліоративно-землеробського природокористування, сильним руральними ознаками, позитивним значенням факторів ерозійної небезпеки ризиками солонцюватості грунтів, перспективами у розвитку елементів екомережі, значною варіативністю умов та чинників розвитку сільської місцевості (суцільна смуга на Лівобережжі Херсонської області, в яку входять Каховський, Новотроїцький, Чаплинський, Скадовський, Каланчацький райони).

Висновки. Запропонований підхід щодо регіонального аналізу природокористування, детальне вивчення картографічних матеріалів щодо сучасної просторової диференціації основних складових суспільно-просторового комплексу Херсонської області мають стати основою виділення геопланувальних мікрорегіонів (3 геопланувальними ділянками), які представляють комплексні ОТО геопланувальної організації СМ 
на регіональному рівні. Суспільно-просторові комплекси геопланувальних мікрорегіонів, виділені 3 використанням зазначених підходів, характеризуються не тільки значними відмінностя- ми у природокористуванні, але і диференціюються за функціями, що виконують території СМ в їх межах, факторами і можливостями подальшого розвитку в контексті планування території.

\section{References:}

1. Bìlokon' U. M. Regional'ne planuvannâ: teorîa ì praktika [Regional planning: theory and practice], Kyiv, 2003, 246 p. (In Ukrainian).

2. Bokov V. A., Timčenko I. E., Červanev I. G., Rudyk A. N. Prostranstvenno-vremennoj analiz vterritorial'nom menedžmente. Čast' 1. Učeb. posobie [Spatial and temporal analysis of the territorial management. Part 1. Textbook]. Simferopol', 2005, 184 p. (In Russian).

3. Buligìn S. Û., Dumìn Û. D., Kucenko M. V. Ocinka geografičnogo seredoviŝa ta optimizacîa zemlekoristuvannâ [Assessment of the geographical environment and optimization of land use], Harkiv, 2002, 168 p. (In Ukrainian).

4. Čarik L. P. Ekologo-geografičnij analiz ì ocìnûvannâ teritorï: teoriâ ta praktika (na materialah Ternopil's'koï oblasti) [Ecological and geographical land analysis and evaluation: theory and practice (based on Ternopil region)], Ternopil', 2006, 256 p. (In Ukrainian).

5. Faŝevskij N. I., Palij T. M., Nemčenko M. P. Territorial'naâ organizaciâžziznedeâtel'nosti naselennâ [Territorial organization of human activity], Kyiv, 1992, 136 p. (In Russian).

6. General'na shema planuvannâ teritorï Ukraïni. Poâsnûval'na zapiska: v $2 t$. [General scheme of territorial planning of Ukraine. Explanatory note. In 2 parts]. Kyiv, DIPROMISTO, 2000. (In Ukrainian).

7. Horev B. S. Territorial'naâ organizaciâ obŝestva (aktual'nye problemy regional'nogo upravleniâ iplanirovaniâ $v$ SSSR) [Territorial organization of society (contemporary issues of regional management and planning in the USSR)]. Moscow, 1981, 320 p. (In Russian).

8. Malchykova D.S. Teoretiko-metodologičnì i metodičnì zasadi geoplanuvannâ sìl'skoï miscevostì na regional'nomu rivni [Theoretical, methodological and methodic principals of rural geoplanning on the regional level], Kherson, 2014, 362 p. (In Ukrainian).

9. Marsden T. New rural territories: regulating the differentiated rural spaces. Journal of Rural Studies, 1998, N. 14 (1), pp.107-117.

10. Mezencev K.V., Pìdgrušnij G.P., Mezenceva N.Ì. Regìonal'nij rozvitok v Ukraïnì: suspil'no-prostorova nerìvnìst' ì polârizaciâ. [Regional Development in Ukraine: the socio-spatial inequality and polarization], Kyiv, 2014, 132 p. (In Ukrainian).

11. Paleha Û., M., Zerkal 'M.V., Oleŝenko A.V., Solomaha İ.V. Metodologiâ provedennâ mìstobudìvnogo nanlìzu pri rozrobcì shemi planuvannâ teritorij Hersons'koï oblastì [Methodology of the analysis of the development of urban planning schemes Kherson region]. Regional'nì problemi Ukrä̈ni: geografičnij analiz ta pošuk šlâhìv virišennâ [Regional issues in Ukraine: geographical analysis and search for solutions], Kherson, 2011, pp. 237-245. (In Ukrainian).

12. Persson L., Westholm E. Towards the new mosaic of rural regions. European Review of Agricultural Economics, 1994, N. 21, pp. 409-427.

13. Pìdgrušnij G.P. Sutnìst' territorial'noï organìzacii suspil'stva iii zakonomìrnostì, procesi ta formi [The essence of the territorial organization of society: laws, processes and forms]. Regional'nì problemi Ukraïni: geografičnij analiz ta pošuk šlâhìv virišsennâ [Regional issues in Ukraine: geographical analysis and search for solutions]. Kherson, 2011, pp. 253-259. (In Ukrainian).

14. Pìstun M. D. Osnovi teoriï suspil'noï geografï [Bases of the theory of social geography], Kyiv, 1996, 231 p. (In Ukrainian).

15. Ploeg J. D., Renting H., Brunori G., Knickel K., Mannion J. et al. Rural development: from practices and policies towards theory. Sociologia Ruralis, 2000, N. 40, pp. 391-408.

16. Šablìj O. İ. Suspìl'na geografiâ: teoriâ, ìstoriâ, ukraïnoznavčì studiï [Social geography: theory, history, Ukrainian studies]. L'vìv, 2001, 744 p. (In Ukrainian).

17. Šiŝenko P.G. Principy $i$ metody landšaftnogo analiza v regional'nom proektirovanii [The principles and methods of landscape analysis in regional planning], Kyiv, 1999, 284 p. (In Russian).

18. Topčiêv O. G. Osnovi suspil'noï geografiï [Bases of the human geography]. Odesa, 2009, 544 p. (In Ukrainian).

19. Topčiêv O. G. Teritoriâ: sučasnij zmìst ponâttâ; funkciï; resursnij potencìal [Territory: modern meaning of the term; function; resource potential]. Ukraïns'kij geografičnij žurnal [Ukrainian Geographical Journal], 2010, N. 4(72), pp. 3-9. (In Ukrainian). 